\title{
Systematic review and meta-analysis on the adverse events of rimonabant treatment: Considerations for its potential use in hepatology
}

\author{
Norberto C Chavez-Tapia*1, Felix I Tellez-Avila², Giorgio Bedogni ${ }^{1}$, \\ Lory S Crocè ${ }^{1,3}$, Flora Masutti ${ }^{1}$ and Claudio Tiribelli1, ${ }^{1,3}$
}

\author{
Address: ${ }^{1}$ Centro Studi Fegato (CSF) - Liver Research Center, Bldg Q - AREA Science Park-Basovizza Campus, Italy, ${ }^{2}$ Department of \\ Gastroenterology Instituto Nacional de Ciencias Médicas y Nutrición Salvador Zubirán, México and ${ }^{3}$ Department ACADEM, University of Trieste, \\ Italy \\ Email: Norberto C Chavez-Tapia* - khavez@gmail.com; Felix I Tellez-Avila - felixtelleza@gmail.com; \\ Giorgio Bedogni - giorgiobedogni@gmail.com; Lory S Crocè - l.croce@csf.units.it; Flora Masutti - fmasutti@csf.units.it; \\ Claudio Tiribelli - ctliver@csf.units.it \\ * Corresponding author
}

Published: 9 October 2009

BMC Gastroenterology 2009, 9:75 doi:10.1 186/1471-230X-9-75

This article is available from: http://www.biomedcentral.com/I47I-230X/9/75

(c) 2009 Chavez-Tapia et al; licensee BioMed Central Ltd.

This is an Open Access article distributed under the terms of the Creative Commons Attribution License (http://creativecommons.org/licenses/by/2.0), which permits unrestricted use, distribution, and reproduction in any medium, provided the original work is properly cited.

\begin{abstract}
Background: The cannabinoid-I receptor blockers have been proposed in the management of obesity and obesity-related liver diseases (fatty liver as NAFLD or NASH). Due to increasing number of patients to be potentially treated and the need to assess the advantage of this treatment in terms of risk/benefit, we analyze the side events reported during the treatment with rimonabant by a systematic review and meta-analysis of all randomized controlled studies.
\end{abstract}

Methods: All published randomized controlled trials using rimonabant versus placebo in adult subjects were retrieved. Relative risks (RR) with $95 \%$ confidence interval for relevant adverse events and number needed to harm was calculated.

Results: Nine trials $(\mathrm{n}=9635)$ were considered. Rimonabant $20 \mathrm{mg}$ was associated with an

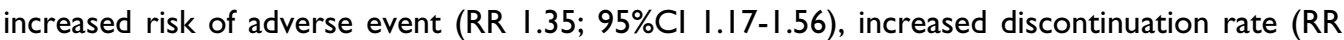

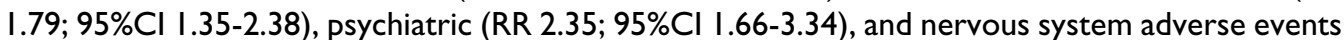
(RR 2.35; 95\% Cl I.49-3.70). The number needed to harm for psychiatric adverse events is 30 .

Conclusion: Rimonabant is associated with an increased risk of adverse events. Despite of an increasing interest for its use on fatty liver, the security profile and efficacy it is needs to be carefully assessed before its recommendation. At present the use of rimonabant on fatty liver cannot be recommended.

\section{Background}

As the consequence of important biologic and social modifications, in the last century new non-infectious epidemic diseases appeared as the most important causes of mortal- ity in worldwide. Among these new epidemic diseases, obesity gained a leader position since the pathologic accumulation of adipose tissue has important deleterious effect on life expectancy $[1,2]$. The metabolic syndrome, 
of which obesity is the most common cause, is considered the most important risk factor for cardiovascular diseases and other chronic diseases [3].

The algorithm for the management of obesity includes non-pharmacologic, pharmacologic and surgery-based strategies [4]. Several drugs are recommended in the pharmacological approach and in the last years the cannabinoid-1 receptor blocker rimonabant has been proposed as a potential effective therapeutic approach in the management of obesity [5].

Non-alcoholic fatty liver disease (NAFLD), the hepatic manifestation of the metabolic syndrome $[6,7]$ has been shown to be present in more that $70 \%$ of the obese subjects [8]. There is a consensus that the key mechanism of hepatic steatosis is the insulin resistance [9]. This observation prompted to investigate new drugs which may be useful in reducing the fatty content in the liver, the cornerstone in the treatment of NAFLD [10]. Although effective, dietary modifications and increased physical activity are associated with a low rate of compliance in the real life since recurrence is almost the rule $[11,12]$. This explains the increased interest shown by both clinicians and industry to find pharmacological approaches. Based on the favorable results of randomized controlled trials assessing rimonabant in the management of obesity, there is an increasing interest to assess the efficacy of this drug in NAFLD. However data of ADAGIO-Lipids trial showed in NAFLD patients a significant improvement of liver function test and liver fat [13], the histological evidence was not evaluated and the two randomized controlled trials on NAFLD $[14,15]$ were stopped prematurely due to request of national health authorities. Small, uncontrolled observations suggested that rimonabant may be an effective strategy in fatty liver [16] in spite of some adverse events [17]. The adverse events have been so far analyzed by meta-analysis of data from Rimonabant In Obesity (RIO) trials $[18,19]$. In this review we extend the study on the side events reported during the treatment with rimonabant by a systematic review and meta-analysis of all randomized controlled studies using this cannabinoid1 receptor blocker in any pathological condition.

\section{Methods}

\section{Criteria for considering studies for this review}

We considered all published randomized controlled trials using rimonabant (any dosage) versus placebo for at least 12 weeks in adults for any clinical indication, regardless of the language of publication. The outcomes were the adverse events reported classified as: 1) any adverse event; 2) serious adverse events; 3 ) discontinuation due to adverse event; 4) discontinuation due psychiatric adverse event; and 5) discontinuation due to neurologic adverse event.

\section{Search methods for identification of studies}

Reported randomized clinical trials were identified by search of The Cochrane Hepato-Biliary Group Controlled Trials Register (May 2009), The Cochrane Library (Issue 2, 2009), EMBASE (January 1980 to May 2009), and MEDLINE (January 1966 to May 2009). Search terms were ("rimonabant" OR "Acomplia" OR ["antagonist" AND "cannabinoid" AND "receptor"]) AND ("randomized controlled trial" OR "random" OR "blinded" OR "controlled") AND "placebo". The references of all identified studies were inspected for more trials. We also checked for any missing trials by examining the references of existing reviews of this topic.

Two authors (NCT, FTA) independently reviewed the search output of potentially relevant trials for inclusion and assessed the trial for inclusion. Studies not meeting the inclusion criteria were excluded. Disagreements were settled by discussion with a third co-author (CT). In an independent manner we assessed the bias risk by the following components of methodological quality of included studies: generation of allocation sequence, allocation concealment, blinding, incomplete outcome data and selective outcome reporting [20].

\section{Statistical analysis}

We use the software package RevMan 5 [21]. For dichotomous variables, we calculate the relative risk (RR) with 95\% confidence interval. A fixed effect model was used throughout the review, except in the event of significant heterogeneity between the trials $(\mathrm{P}<0.10)$, when the random effect model was chosen. Heterogeneity was explored by chi-squared test with significance set at Pvalue 0.10 , and the quantity of heterogeneity was measured by $\mathrm{I}^{2}[22]$. We use a funnel plot to explore bias. Asymmetry in funnel plot of trial size against treatment effect was used to assess this bias. We perform linear regression approach described by Egger $e t$ al. to determine the funnel plot asymmetry [23]. Number needed to harm was calculated.

\section{Results}

The initial search strategy included 386 references. Out of these studies, 26 studies were considered further and 10 randomized controlled trials were finally found suitable for the analysis [13,24-32]. Out of the 10 trials one was excluded because no adverse effects were reported (Figure 1) [31].

The characteristics and quality of studies included are reported in Table 1. All trials had a low risk of bias. Five trials were designed to assess the efficacy on weight reduction, one for the percent change of atheroma volume, one for the management of alcohol dependency, one to assess the changes in $\mathrm{HbA}_{1 \mathrm{c}}$; one for hyperandrogenaemia; one 


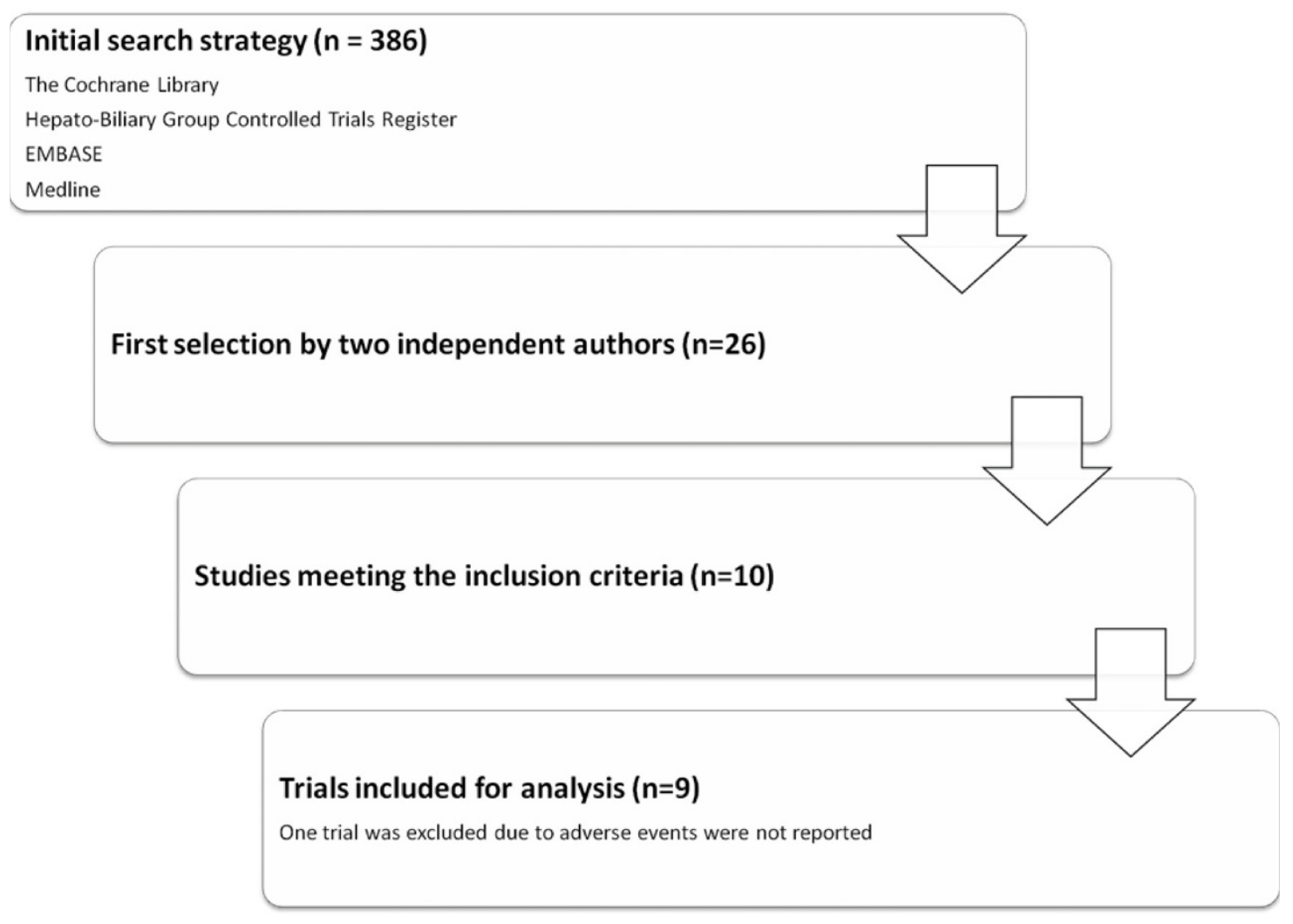

\section{Figure I}

Flow chart for search strategy and selection of trials.

for change in lipid profile, and one was designed to assess insulin resistance in patients with polycystic ovary syndrome. The last one was the excluded study since the adverse events were not reported. The longest follow-up was 24 months with a range between 3 and 24 months. A pooled 2849 subjects were included in the placebo arm, 2883 in rimonabant $5 \mathrm{mg}$ arm, and 3903 were assigned to rimonabant $20 \mathrm{mg}$. In the serious adverse events, discontinuations for adverse events and psychiatric adverse events analysis biases were observed in the funnel plot graph (Additional file 1).

\section{Adverse events}

The use of rimonabant at dosage of $5 \mathrm{mg}$ was not associated with any adverse event. Conversely, the use of $20 \mathrm{mg}$ was associated with an increased risk for adverse event $v s$. placebo (RR 1.35; 95\%CI 1.17-1.56), with a pooled effect of increased risk (RR 1.21; 95\%CI 1.09-1.34) (Figure 2). By assessing only serious adverse events, a trend for increased risk in the rimonabant groups was observed at both dosages ( 5 and $20 \mathrm{mg}$ ), although the difference did not reach statistical significance (RR 1.16; 95\%CI 0.931.45) (Additional file 2). In the subjects receiving $5 \mathrm{mg}$ rimonabant, no difference was found in the discontinuation rate for adverse events while in those receiving $20 \mathrm{mg}$ rimonabant an association between drug use and discontinuation rate (RR $1.79 ; 95 \%$ CI 1.35-2.38) was observed. The same was found when data obtained in pooled series (5 and $20 \mathrm{mg}$ of rimonabant) were considered (RR 1.47; 95\%CI 1.15-1.87 for) (Figure 3).

By performing a sub-analysis of the psychiatric adverse events forcing treatment discontinuation we observed that only rimonabant at dosage of $20 \mathrm{mg}$ was associated with an increased risk of psychiatric disorders (RR 2.35; 95\%CI 1.66-3.34), a difference which remains after pooling both dosages (RR 1.79; 95\%CI 1.24-2.58) (Figure 4). Similarly, $20 \mathrm{mg}$ rimonabant and pooled data of the two dosages were associated with increased risk for treatment discontinuation due nervous system adverse events (RR 2.35; 95\%CI 1.49-3.70 and, RR 1.89; 95\%CI 1.30-2.75, respectively) (Figure 5).

The analysis of the number needed to harm (NNH) demonstrates a reduced $\mathrm{NNH}$ for the occurrence of any adverse event (NNH 22, for rimonabant $20 \mathrm{mg}$ ), and dis- 
Table I: Methodological quality summary: review authors' judgments about each methodological quality item for each included study.

\begin{tabular}{|c|c|c|c|c|c|c|c|c|}
\hline $\begin{array}{l}\text { Author } \\
\text { (year) }\end{array}$ & $\begin{array}{l}\text { Subjects } \\
\text { included }\end{array}$ & $\begin{array}{l}\text { Duration } \\
\text { (months) }\end{array}$ & $\begin{array}{l}\text { Primary } \\
\text { outcome }\end{array}$ & $\begin{array}{l}\text { Adequate } \\
\text { sequence } \\
\text { generation }\end{array}$ & $\begin{array}{l}\text { Allocation } \\
\text { concealment }\end{array}$ & Blinding & $\begin{array}{l}\text { Incomplete } \\
\text { outcome } \\
\text { data }\end{array}$ & $\begin{array}{l}\text { Selective } \\
\text { outcome } \\
\text { reporting }\end{array}$ \\
\hline $\begin{array}{l}\text { Van Gaal } \\
(2005)^{*}\end{array}$ & $\begin{array}{l}\text { placebo }=305 \\
\text { rimonabant } 5 \\
\mathrm{mg}=603 \\
\text { rimonabant } 20 \\
\mathrm{mg}=599\end{array}$ & 12 & Weight change & Yes & Yes & Yes & No & No \\
\hline $\begin{array}{l}\text { Després } \\
(2005)^{*}\end{array}$ & $\begin{array}{l}\text { placebo }=342 \\
\text { rimonabant } 5 \\
\mathrm{mg}=345 \\
\text { rimonabant } 20 \\
\mathrm{mg}=346\end{array}$ & 12 & Weight change & Yes & Yes & Yes & No & No \\
\hline $\begin{array}{l}\text { Pi-Sunyer } \\
(2006)^{*}\end{array}$ & $\begin{array}{l}\text { placebo }=607 \\
\text { rimonabant } 5 \\
\mathrm{mg}=1214 \\
\text { rimonabant } 20 \\
\mathrm{mg}=1219\end{array}$ & 12 & Weight change & Yes & Yes & Yes & No & No \\
\hline $\begin{array}{l}\text { Scheen } \\
(2006)^{*}\end{array}$ & $\begin{array}{l}\text { placebo }=348 \\
\text { rimonabant } 5 \\
\mathrm{mg}=358 \\
\text { rimonabant } 20 \\
\mathrm{mg}=339\end{array}$ & 12 & Weight change & Yes & Yes & Yes & No & No \\
\hline $\begin{array}{l}\text { Nissen } \\
(2008)\end{array}$ & $\begin{array}{l}\text { rimonabant } 20 \\
\mathrm{mg}=422\end{array}$ & 18 & $\begin{array}{l}\text { Change in } \\
\text { percent } \\
\text { atheroma } \\
\text { volume }\end{array}$ & Yes & Yes & Yes & No & No \\
\hline $\begin{array}{l}\text { Van Gaal } \\
(2008)^{*}\end{array}$ & $\begin{array}{l}\text { placebo }=168 \\
\text { rimonabant } 5 \\
\mathrm{mg}=363 \\
\text { rimonabant } 20 \\
\mathrm{mg}=305\end{array}$ & 24 & Weight change & Yes & Yes & Yes & No & No \\
\hline Soyka (2008) & $\begin{array}{l}\text { placebo }=127 \\
\text { rimonabant } 20 \\
\mathrm{mg}=131\end{array}$ & 3 & $\begin{array}{l}\text { Time to first } \\
\text { drink } \\
\text { Time to relapse } \\
\text { to first heavy } \\
\text { drinking }\end{array}$ & Yes & Yes & Yes & No & No \\
\hline $\begin{array}{l}\text { Rosenstock } \\
\text { (2008) }\end{array}$ & $\begin{array}{l}\text { Placebo = I } 40 \\
\text { Rimonabant } \\
20 \mathrm{mg}=138\end{array}$ & 6 & $\mathrm{HbA}_{\mathrm{lc}}$ & NR & NR & Yes & No & No \\
\hline $\begin{array}{l}\text { Després } \\
\text { (2009) }\end{array}$ & $\begin{array}{l}\text { Rimonabant } \\
20 \mathrm{mg}=404\end{array}$ & 12 & $\begin{array}{l}\text { Change in HDL } \\
\text { cholesterol and } \\
\text { triglycerides }\end{array}$ & Yes & Yes & Yes & No & No \\
\hline
\end{tabular}

\footnotetext{
* The articles with asterisk are part of Rimonabant In Obesity (RIO) trials
} 


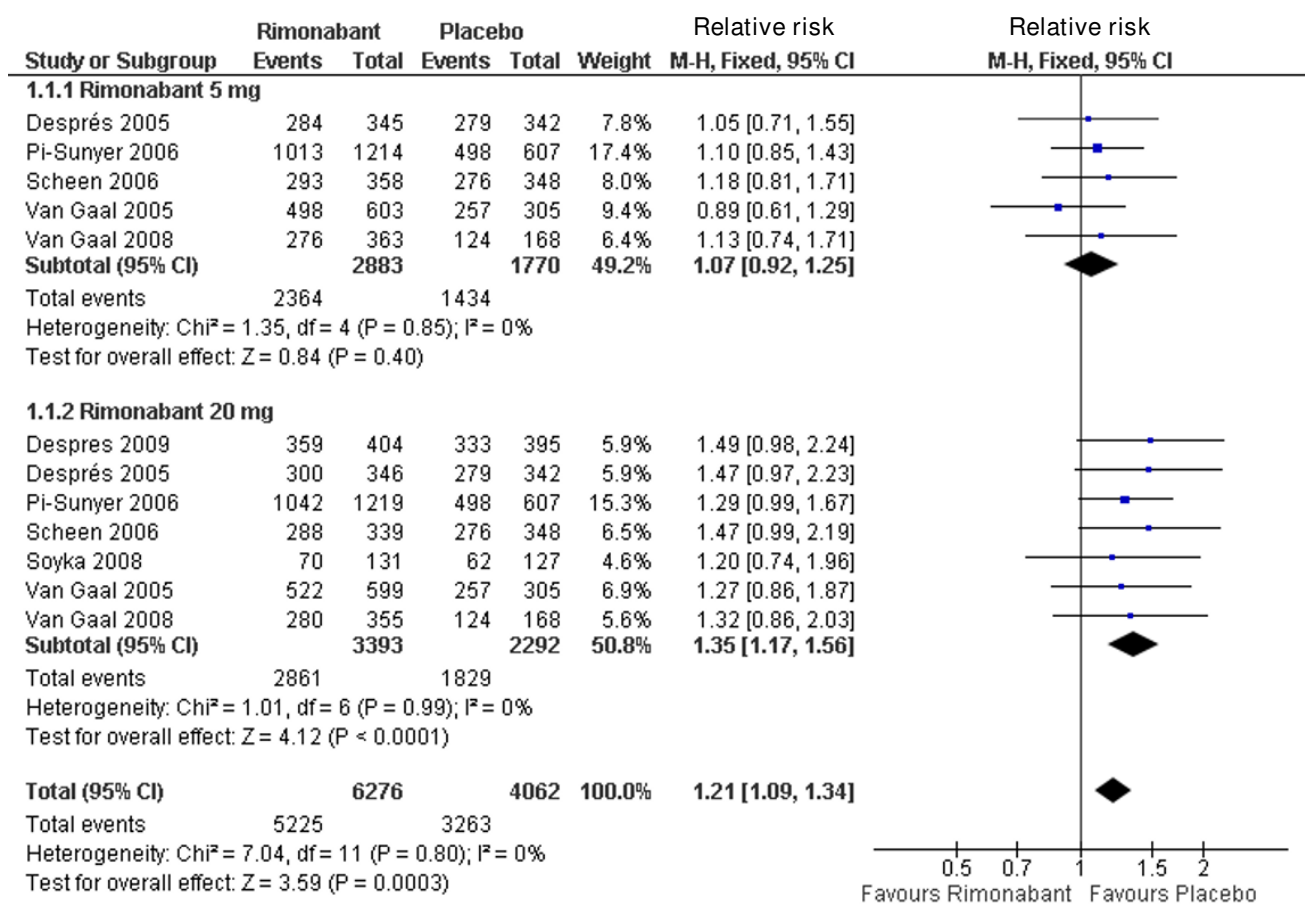

Figure 2

Forest plot graphic assessing the risk to be free of any adverse events at rimonabant dosages of 5 and 20 mg.

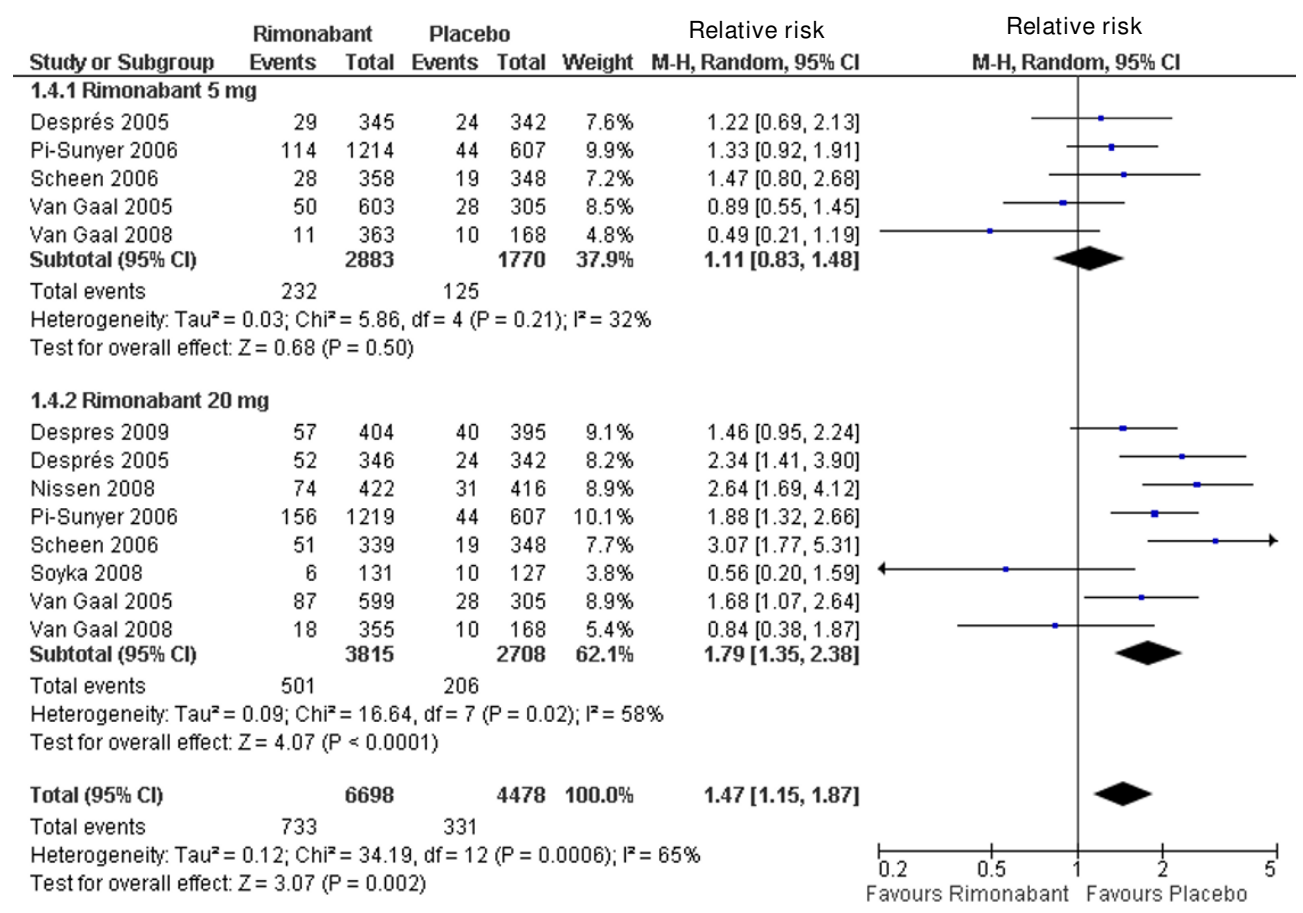

Figure 3

Forest plot graphic assessing the risk to be free of discontinuation due to adverse events at rimonabant dosages of 5 and $20 \mathrm{mg}$. 


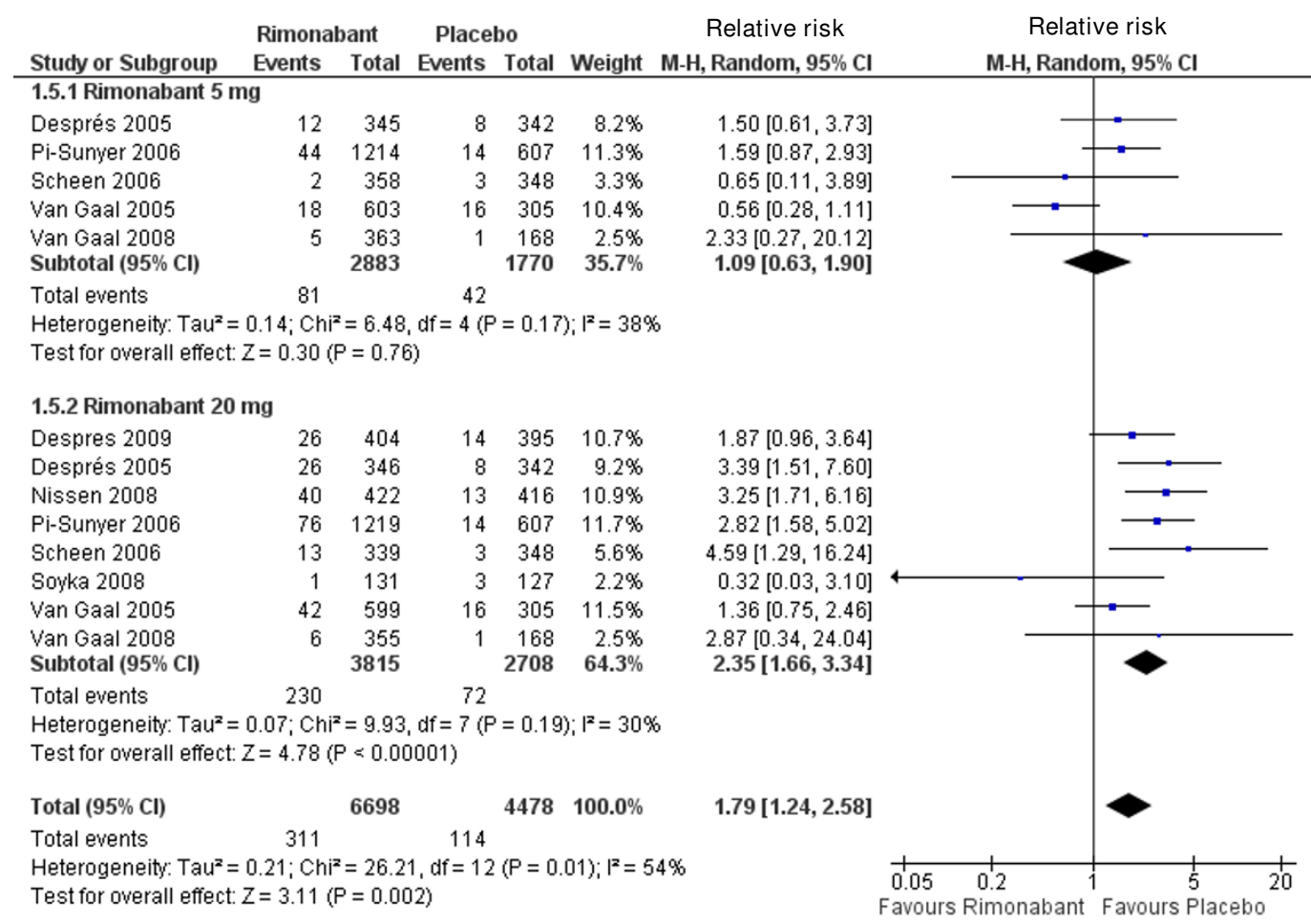

\section{Figure 4}

Forest plot graphic assessing the risk to be free of treatment discontinuation due to psychiatric adverse events at rimonabant dosages of 5 and $20 \mathrm{mg}$.

continuation due to adverse events (NNH 18, for rimonabant $20 \mathrm{mg}$ ). It was also found that for every 30 patients treated with $20 \mathrm{mg}$ rimonabant, one will discontinue the treatment due to psychiatric adverse events (Table 2).

\section{Discussion}

In this study we performed a meta-analysis on the adverse events related with the treatment with rimonabant, a cannabinoid-1 receptor blocker, used primarily in obesity and related disorders. We observed that the use of rimonabant at the dose of $20 \mathrm{mg}$ per day is associated with adverse events including discontinuation due to psychiatric and neurologic adverse events. These results are similar to those reported in previous meta-analysis on the Rimonabant in Obesity (RIO) trials [33]. However our study included more studies as a trial for alcohol dependence which enrolled subjects without obesity but with greater risk to present adverse events (particularly psychiatric adverse events).

The NNH to discontinuation due to adverse in our study were similar to other meta-analysis (NNH 14). Of notice that this NNH is the lowest as compared to other drugs for obesity treatment (NNH 39, for orlistat; and NNH 500, for sibutramine). Given the large number of patients eligi- ble for the treatment with rimonabant, the NNH is a concern [33].

The results of this meta-analysis also suggest that subjects exposed to $20 \mathrm{mg}$ rimonabant may have some clinically relevant adverse events, and point to the need that both patients and investigators should be alerted about the early detection of these negative events. Since there is no evidence on the clinical utility and due to the proved evidence of increased adverse events rate, rimonabant cannot be recommended as a treatment option in NAFLD. This is further supported by the finding that despite possible reduction in the hepatic fat content [13], no evidence regarding histological improvement exists also because of the premature stop of rimonabant registered trials in NALFD [14,15], and other diseases (ClinicalTrials.gov registry: NCT00547118, NCT00678483, NCT00754689, NCT00434096, NCT00412698, NCT00449605, NCT00263042, NCT00690456, NCT00228176, NCT00478972, NCT00478595, NCT00405808, NCT00458081, NCT00325650, NCT00408148).

Nowadays solid information shows that rather than a totally benign disease, NAFLD may be a cause of chronic liver disease with a potential risk to develop end-stage 


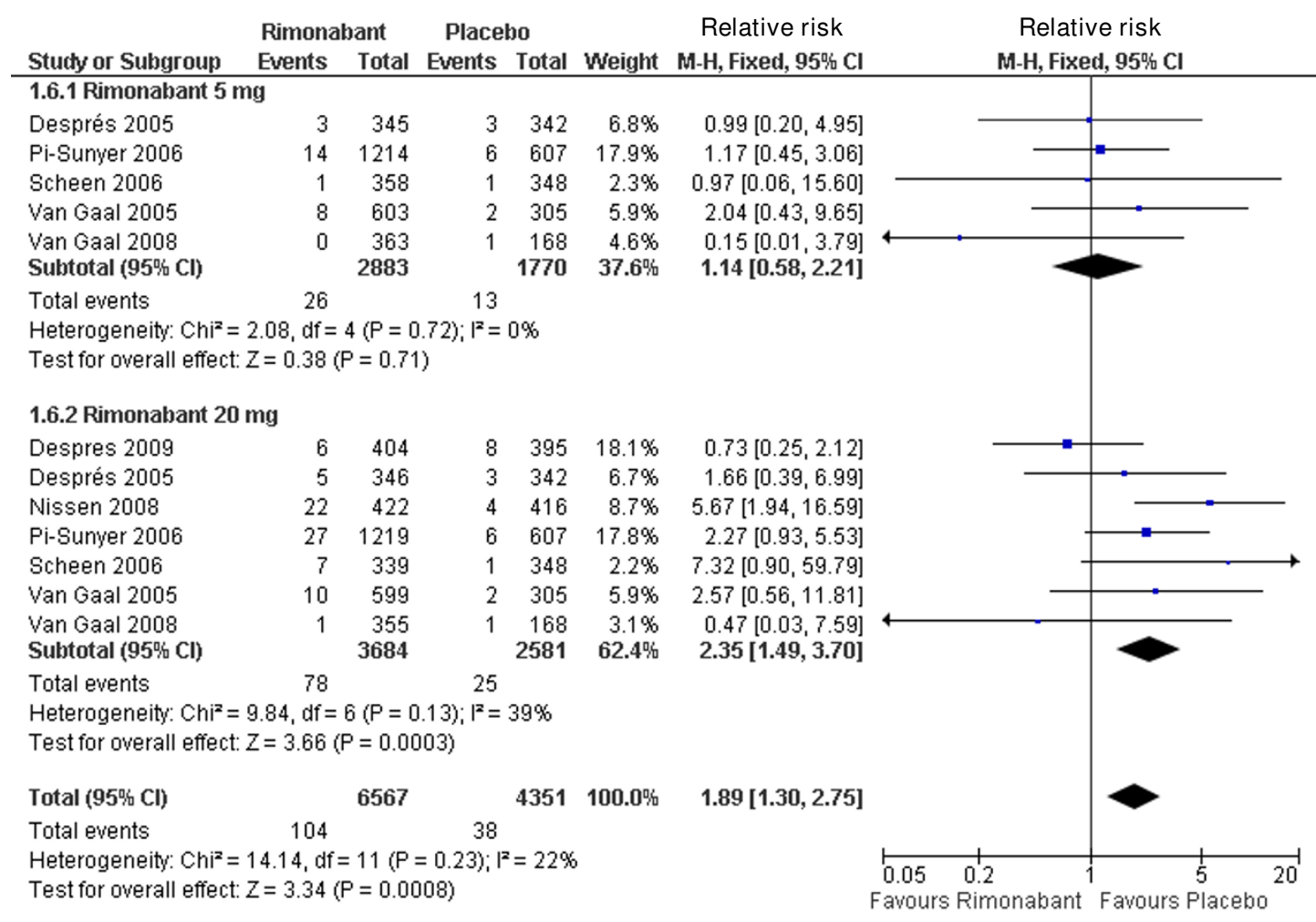

Figure 5

Forest plot graphic assessing the risk to be free of treatment discontinuation due to neurologic adverse events at rimonabant dosages of 5 and $20 \mathrm{mg}$.

Table 2: Number need to harm (NNH) to each adverse event assessed in the meta-analysis.

\begin{tabular}{|c|c|c|c|c|c|c|c|}
\hline & Rimonabant treated & Event & Placebo treated & Event & CER (\%) & EER (\%) & NNH \\
\hline \multicolumn{8}{|l|}{ Any adverse event } \\
\hline Rimonabant 5 mg & 2883 & 2364 & 1770 & 1434 & 81 & 82 & 102 \\
\hline Rimonabant 20 mg & 3393 & 2861 & 2292 & 1829 & 80 & 84 & 22 \\
\hline Total & 6276 & 5225 & 4062 & 3263 & 80 & 83 & 34 \\
\hline \multicolumn{8}{|l|}{ Serious adverse events } \\
\hline Rimonabant 5 mg & 2883 & 149 & 1770 & 79 & 4 & 5 & 142 \\
\hline Rimonabant 20 mg & 3393 & 207 & 2292 & 123 & 5 & 6 & 136 \\
\hline Total & 6276 & 356 & 4062 & 202 & 5 & 6 & 143 \\
\hline \multicolumn{8}{|c|}{ Discontinuation due to adverse events } \\
\hline Rimonabant 5 mg & 2883 & 232 & 1770 & 125 & 7 & 8 & 102 \\
\hline Rimonabant 20 mg & 3815 & 501 & 2708 & 206 & 8 & 13 & 18 \\
\hline Total & 6698 & 733 & 4478 & 331 & 7 & 11 & 28 \\
\hline \multicolumn{8}{|c|}{ Discontinuation due to psychiatric adverse events } \\
\hline Rimonabant 5 mg & 2883 & 81 & 1770 & 42 & 2 & 3 & 229 \\
\hline Rimonabant $20 \mathrm{mg}$ & 3815 & 230 & 2708 & 72 & 3 & 6 & 30 \\
\hline Total & 6698 & 311 & 4478 & 114 & 3 & 5 & 48 \\
\hline \multicolumn{8}{|c|}{ Discontinuation due to neurologic adverse events } \\
\hline Rimonabant 5 mg & 2883 & 26 & 1770 & 13 & 1 & 1 & 597 \\
\hline Rimonabant $20 \mathrm{mg}$ & 3684 & 78 & 2581 & 25 & 1 & 2 & 87 \\
\hline Total & 6567 & 104 & 4351 & 38 & 1 & 2 & $14 \mid$ \\
\hline
\end{tabular}

CER, control event rate; EER, experimental event rate. 
liver disease complications that had a deleterious effect in mortality rates [34]. Considering the short period of time since its first description, all therapeutic approaches (pharmacologic or non-pharmacologic, such as dietary) had not been properly assessed, and the standard of care of this disease usually follows the guidelines of obesityrelated disorders [35]. During the last 25 years the scientists demonstrate an increased interest in obesity-related liver complications, and exciting findings about the noxious relationship among the liver and fat tissue were described [34]. Promote new therapies is one face of the coin but proper detection of the potential adverse effects and/or undesirable outcomes must be carefully considered to be sure to satisfy our goal.

\section{Conclusion}

In conclusion the use of rimonabant at $20 \mathrm{mg}$ per day is associated with clinical adverse events. At present no indication on the use of this drug on NAFLD exists and therefore it cannot be suggested.

\section{Abbreviations}

NAFLD: non-alcoholic fatty liver disease; RR: relative risk; NNH: number needed to harm.

\section{Competing interests}

The authors declare that they have no competing interests.

\section{Authors' contributions}

NCT conceived, design, co-ordinated, collect, analyzed, interpreted data, wrote and approved the manuscript. FTA collected, analyzed, interpreted data, corrected and approved the manuscript. GB analyzed, interpreted data, corrected and approved the manuscript. LC provided general advice, read and approved the manuscript. FM provided general advice, read and approved the manuscript. CT interpreted data, corrected and approve the manuscript.

\section{Additional material}

\section{Additional file 1}

Figure S1. Funnel plot graphic, indicating bias in those studies reporting: a) serious adverse events, $b$ ) discontinuation due to adverse effect, and c) discontinuation due to psychiatric disorders.

Click here for file

[http://www.biomedcentral.com/content/supplementary/1471230X-9-75-S1.PDF]

\section{Additional file 2}

Figure S2. Forest plot graphic assessing the risk to be free of present serious adverse events at rimonabant dosages of 5 and $20 \mathrm{mg}$.

Click here for file

[http://www.biomedcentral.com/content/supplementary/1471230X-9-75-S2.PDF]

\section{Acknowledgements}

NCT was supported by a grant from Centro Studi Fegato, and partially supported by The Dame Sheila Sherlock EASL Fellowship program. Part of this manuscript was supported by in house grant from Fondazione Italiana Fegato.

\section{References}

I. Al Snih S, Ottenbacher KJ, Markides KS, Kuo YF, Eschbach K, Goodwin JS: The effect of obesity on disability vs mortality in older Americans. Archives of internal medicine 2007, 167(8):774-780.

2. Adams KF, Schatzkin A, Harris TB, Kipnis V, Mouw T, Ballard-Barbash R, Hollenbeck A, Leitzmann MF: Overweight, obesity, and mortality in a large prospective cohort of persons 50 to 71 years old. The New England journal of medicine 2006, 355(8):763-778.

3. Skilton MR, Moulin P, Serusclat A, Nony P, Bonnet F: A comparison of the NCEP-ATPIII, IDF and AHA/NHLBI metabolic syndrome definitions with relation to early carotid atherosclerosis in subjects with hypercholesterolemia or at risk of CVD: evidence for sex-specific differences. Atherosclerosis 2007, 190(2):416-422.

4. Lau DC, Douketis JD, Morrison KM, Hramiak IM, Sharma AM, Ur E: 2006 Canadian clinical practice guidelines on the management and prevention of obesity in adults and children [summary]. Cmaj 2007, I76(8):SI-I3.

5. Rubio MA, Gargallo M, Isabel Millan A, Moreno B: Drugs in the treatment of obesity: sibutramine, orlistat and rimonabant. Public health nutrition 2007, I0(I0A): I200- 1205.

6. Loria P, Lonardo A, Carulli L, Verrone AM, Ricchi M, Lombardini S, Rudilosso A, Ballestri S, Carulli N: Review article: the metabolic syndrome and non-alcoholic fatty liver disease. Alimentary pharmacology \& therapeutics 2005, 22(Suppl 2):3I-36.

7. Musso G, Gambino R, Bo S, Uberti B, Biroli G, Pagano G, Cassader $M$ : Should nonalcoholic fatty liver disease be included in the definition of metabolic syndrome? A cross-sectional comparison with Adult Treatment Panel III criteria in nonobese nondiabetic subjects. Diabetes care 2008, 3 I (3):562-568.

8. Bugianesi E, Bellentani S, Tiribelli C, Svegliati Baroni G, Croce LS, Gastaldelli A, Marchesini G, Perseghin G, Tell G: Clinical update on non-alcoholic fatty liver disease and steatohepatitis. Annals of Hepatology 2008, 7(2): 157-160.

9. Marra F, Gastaldelli A, Svegliati Baroni G, Tell G, Tiribelli C: Molecular basis and mechanisms of progression of non-alcoholic steatohepatitis. Trends in molecular medicine 2008, I 4(2):72-8I.

10. Marchesini G, Natale S, Manini R, Agostini F: Review article: the treatment of fatty liver disease associated with the metabolic syndrome. Alimentary pharmacology \& therapeutics 2005, 22(Suppl 2):37-39.

II. Zhao G, Ford ES, Li C, Mokdad AH: Compliance with physical activity recommendations in US adults with diabetes. Diabet Med 2008, 25(2):22I-227.

12. Bellentani S, Dalle Grave R, Suppini A, Marchesini G: Behavior therapy for nonalcoholic fatty liver disease: The need for a multidisciplinary approach. Hepatology (Baltimore, Md) 2008, 47(2):746-754.

13. Despres JP, Ross R, Boka G, Almeras N, Lemieux I: Effect of rimonabant on the high-triglyceride/low-HDL-cholesterol dyslipidemia, intraabdominal adiposity, and liver fat: the ADAGIO-Lipids trial. Arteriosclerosis, thrombosis, and vascular biology 2009, 29(3):416-423.

14. An Efficacy and Safety Study of Rimonabant for Treatment of Nonalcoholic Steatohepatitis (NASH) in Patients With \begin{tabular}{l} 
Type 2 Diabetes [http://clinicaltrials.gov/ct2/show/ \\
\hline
\end{tabular} NCT00577|48?term=fatty+liver\&rank=39]

15. An Efficacy and Safety Study of Rimonabant for Treatment of Nonalcoholic Steatohepatitis (NASH) in Patients Without Diabetes [http://clinicaltrials.gov/ct2/show/ NCT00576667?term =fatty+liver\&rank $=40]$

16. Banasch M, Goetze O, Schmidt WE, Meier J]: Rimonabant as a novel therapeutic option for nonalcoholic steatohepatitis. Liver Int 2007, 27(8): I I52-I I 55.

17. Kashi MR, Torres DM, Harrison SA: Current and emerging therapies in nonalcoholic fatty liver disease. Seminars in liver disease 2008, 28(4):396-406.

18. Christensen R, Kristensen PK, Bartels EM, Bliddal H, Astrup A: Efficacy and safety of the weight-loss drug rimonabant: a meta- 
analysis of randomised trials. Lancet 2007, 370(9600): 1706-17|3.

19. Curioni C, Andre C: Rimonabant for overweight or obesity. Cochrane database of systematic reviews (Online) 2006:CD006I62.

20. Lundh A, Gotzsche PC: Recommendations by Cochrane Review Groups for assessment of the risk of bias in studies. BMC medical research methodology 2008, 8:22.

21. Centre TNC: Review Manager (RevMan). In Version 5 for Windows edn Copenhagen: The Cochrane Collaboration; 2008.

22. Higgins JP, Thompson SG: Quantifying heterogeneity in a metaanalysis. Statistics in medicine 2002, 2 ( (I I):1539-1558.

23. Egger M, Davey Smith G, Schneider M, Minder C: Bias in metaanalysis detected by a simple, graphical test. BMJ (Clinical research ed) 1997, 31 5(7 1 09):629-634.

24. Van Gaal LF, Rissanen AM, Scheen AJ, Ziegler O, Rossner S: Effects of the cannabinoid-I receptor blocker rimonabant on weight reduction and cardiovascular risk factors in overweight patients: I-year experience from the RIO-Europe study. Lancet 2005, 365(9468): 1389-1397.

25. Pi-Sunyer FX, Aronne LJ, Heshmati HM, Devin J, Rosenstock J: Effect of rimonabant, a cannabinoid-I receptor blocker, on weight and cardiometabolic risk factors in overweight or obese patients: RIO-North America: a randomized controlled trial. Jama 2006, 295(7):76I-775.

26. Despres JP, Golay A, Sjostrom L: Effects of rimonabant on metabolic risk factors in overweight patients with dyslipidemia. The New England journal of medicine 2005, 353(20):2I 2 I-2I 34 .

27. Scheen AJ, Finer N, Hollander P, Jensen MD, Van Gaal LF: Efficacy and tolerability of rimonabant in overweight or obese patients with type 2 diabetes: a randomised controlled study. Lancet 2006, 368(9548): I660-1672.

28. Nissen SE, Nicholls SJ, Wolski K, Rodes-Cabau J, Cannon CP, Deanfield JE, Despres JP, Kastelein JJ, Steinhubl SR, Kapadia S, et al.: Effect of rimonabant on progression of atherosclerosis in patients with abdominal obesity and coronary artery disease: the STRADIVARIUS randomized controlled trial. Jama 2008, 299(13): I547-I560.

29. Van Gaal L, Pi-Sunyer X, Despres JP, McCarthy C, Scheen A: Efficacy and safety of rimonabant for improvement of multiple cardiometabolic risk factors in overweight/obese patients: pooled I-year data from the Rimonabant in Obesity (RIO) program. Diabetes care 2008, 3 I (Suppl 2):S229-240.

30. Soyka M, Koller G, Schmidt P, Lesch OM, Leweke M, Fehr C, Gann H, Mann KF: Cannabinoid Receptor I Blocker Rimonabant (SR 14I716) for Treatment of Alcohol Dependence: Results From a Placebo-Controlled, Double-Blind Trial. Journal of clinical psychopharmacology 2008, 28(3):317-324.

31. Sathyapalan T, Cho L, Kilpatrick ES, Coady AM, Atkin SL: A comparison between rimonabant and metformin in reducing biochemical hyperandrogenaemia and insulin resistance in patients with polycystic ovary syndrome: a randomised open labelled parallel study. Clinical endocrinology 2008, 69(6):93 I-5.

32. Rosenstock J, Hollander P, Chevalier S, Iranmanesh A: The SERENADE Trial: Effects of Monotherapy with Rimonabant, the First Selective CB I Receptor Antagonist, on Glycemic Control, Body Weight and Lipid Profile in Drug-naive Type 2 Diabetes. Diabetes care 2008, 3 I (I I):2169-76.

33. Johansson K, Neovius K, Desantis SM, Rossner S, Neovius M: Discontinuation due to adverse events in randomized trials of orlistat, sibutramine and rimonabant: a meta-analysis. Obes Rev 2009, I0(5):564-75.

34. Bellentani S, Bedogni G, Tiribelli C: Liver and heart: a new link? Journal of hepatology 2008, 49(2):300-302.

35. Lau DC: Synopsis of the $\mathbf{2 0 0 6}$ Canadian clinical practice guidelines on the management and prevention of obesity in adults and children. Cmaj 2007, I76(8): I I03-II06.

\section{Pre-publication history}

The pre-publication history for this paper can be accessed here:

http://www.biomedcentral.com/1471-230X/9/75/pre pub

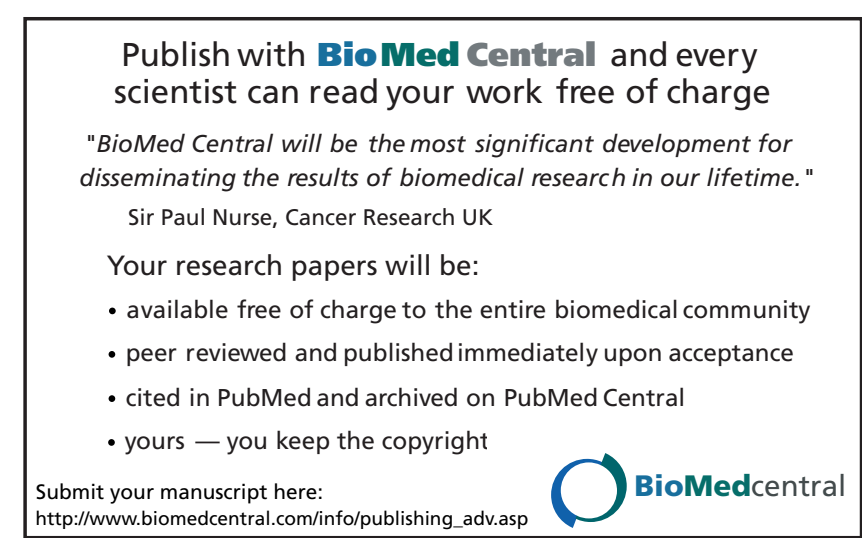

